\title{
Population fluctuation in soil meso- and macrofauna by the successive application of pig slurry ${ }^{1}$
}

\author{
Flutuação populacional da meso e macrofauna edáfica pela aplicação sucessiva de \\ dejeto líquido de suínos
}

\author{
Rodrigo Ferreira da Silva ${ }^{2 *}$, Gilvan Moisés Bertollo ${ }^{3}$, Zaida Inês Antoniolli ${ }^{4}$, Geomar Mateus Corassa ${ }^{3}$ and \\ Cassiano Carlos Kuss ${ }^{3}$
}

\begin{abstract}
Pig farming has increased in recent years, resulting in the production of a large quantity of liquid manure, which can be used as a source of organic fertiliser. The aim of this work was to determine the influence of pig slurry on the community of soil fauna in a system of direct seeding. The study was carried out in an experimental area in the town of Taquaruçu do Sul, in the state of Rio Grande do Sul, Brazil. The experimental design was of randomised blocks in a $(4+1) \times 4$ factorial scheme, comprising five fertilisation treatments, 0 (no fertiliser), 20, 40 and $80 \mathrm{~m}^{3}$ of pig slurry ha $\mathrm{h}^{-1}$ and one additional treatment (mineral fertiliser), with four evaluations corresponding to the number of slurry application (1st, 2nd, 3rd and 4th application), and four replications. The soil fauna was sampled using PROVID traps. The following were evaluated: the relative frequency of the groups of soil fauna, the populations of springtails and mites, density, richness, Simpson's dominance index and the Shannon diversity index. The populations of mites and springtails, and indices of diversity, richness and dominance are influenced by the successive application of pig slurry. Successive applications of pig slurry increase the diversity of the soil fauna by reducing the population of organisms of the Order Collembola. Canonical correlation analysis showed an association between the number of springtails and $80 \mathrm{~m}^{3}$ of pig slurry ha ${ }^{-1}$ after the third application.
\end{abstract}

Key words: Soil fauna. Liquid waste. Direct planting.

RESUMO - A criação de suínos tem aumentado nos últimos anos, ocasionando a produção de elevada quantidade de dejeto líquido, cuja alternativa para seu uso é a aplicação no solo como fonte de fertilizante orgânico. O objetivo do trabalho foi determinar a influência de dejeto líquido de suínos na comunidade da fauna do solo em sistema plantio direto. O trabalho foi desenvolvido em área experimental no município de Taquaruçu do Sul-RS. O delineamento experimental foi em blocos casualizados em arranjo fatorial (4+1) x 4, sendo cinco tratamentos de adubações: 0 (sem adubo), 20; 40 e $80 \mathrm{~m}^{3} \mathrm{ha}^{-1}$ de dejetos líquido de suínos e tratamento adicional (adubação mineral) e quatro avaliações: correspondendo ao número de aplicações do dejeto líquido de suínos $\left(1^{\mathrm{a}}, 2^{\mathrm{a}}, 3^{\mathrm{a}}\right.$ e $4^{\mathrm{a}}$ aplicação), com quatro repetições. As coletas da fauna edáfica foram realizadas com armadilhas tipo PROVID. Avaliou-se a frequência relativa dos grupos da fauna edáfica, população de colêmbolos e ácaros, densidade, riqueza, índice dominância de Simpson e diversidade de Shannon. A população de ácaros e colêmbolos e os índices de diversidade, riqueza e dominância são influenciados pela aplicação sucessiva de dejeto líquido de suínos. Aplicações sucessivas de dejeto líquido de suíno aumenta a diversidade da fauna do solo pela redução na população de organismos da ordem Collembola. A análise de correlação canônica evidenciou associação do número de colêmbolos com $80 \mathrm{~m}^{3} \mathrm{ha}^{-1}$ de dejeto líquido de suínos após a terceira aplicação.

Palavras-chave: Fauna do solo. Resíduos líquidos. Plantio direto.

\footnotetext{
DOI: $10.5935 / 1806-6690.20160026$

*Autor para correspondência

'Recebido para publicação em 28/05/2014; aprovado em 19/11/2015

Pesquisa financiada pela FAPERGS

${ }^{2}$ Departamento de Ciências Agronômicas e Ambientais, Universidade Federal de Santa Maria, Campus Frederico Westphalen, Linha 7 de Setembro, Br 386, Km 40, Santa Maria-RS, Brasil, 98.400-000, rodrigosilva@ smail.ufsm.br

${ }^{3}$ Programa de Pós Graduação em Agronomia Agricultura e Ambiente/PPGAAA, Universidade Federal de Santa Maria, Campus Frederico Westphalen, Linha 7 de Setembro, Br 386, Km 40, Santa Maria-RS, Brasil, 98.400-000, gilvanbertollo@yahoo.com.br, geomarmateus@hotmail.com, cassianok2012@gmail.com

${ }^{4}$ Departamento de Solos, Universidade Federal de Santa Maria, campus sede, Av. Roraima nº 1000, Cidade Universitária, Camobi, Santa Maria-RS, Brasil, 97.105-000, zantoniolli@gmail.com
} 


\section{INTRODUCTION}

In Brazil, pig farming is an activity generally found on small farms in the states of Rio Grande do Sul (RS) and Santa Catarina (GIROTTO et al., 2010). The animals remain on these properties in total confinement until they are slaughtered, resulting in the accumulation of waste in the breeding units (AITA et al., 2006). The need to discard this waste, and the technical and financial limitations on implementing more complex treatment solutions, leads producers to dispose of the slurry on agricultural land (DAL BOSCO et al., 2008).

However, adding organic waste to cropping systems is a factor that can influence the soil biota, mainly by providing food, and by changes in soil temperature and ground cover (BARETTA et al., 2003). Tessaro et al. (2013), evaluating the effect of the application of pig slurry on the density and diversity of soil macrofauna, noted that the edaphic groups displayed different responses to the treatments, the most significant being those of the groups of Hymenoptera and Collembola, with a substantial increase in ant density up to a dose of $200 \mathrm{~m}^{3} \mathrm{ha}^{-1}$. Antoniolli et al. (2006) demonstrated the higher density of the Order Collembola, together with Acarina, in places that had received $80 \mathrm{~m}^{3}$ of pig slurry ha-1. While in tests for toxicity, the heavy metals $\mathrm{Cu}$ and $\mathrm{Zn}$, present in the pig slurry, was reported as being lethal to the Collembola group (SEGAT, 2012).

Soil organisms contribute to nutrient cycling and are affected by changes on the soil surface. These organisms occupy various trophic levels of the soil food web, and affect primary production both directly and indirectly (AQUINO et al., 2008). Modifications to soil macrofauna may occur due to land use, changes to the environment, the preparation and cultivation of the soil, and the addition of organic matter (BARETTA et al., 2007). Mesofauna organisms, such as mites, springtails (Collembola) and Hymenoptera, are considered to be indicators of soil quality, as they are numerically more representative and are sensitive to changes in the physical, chemical and biological characteristics of the soil, (BARTZ et al., 2014; CREPALDI et al., 2014; BELLINGER et al., 2015). Defining changes in soil fauna is therefore important to enable the proper use of organic waste, in order to expand the biological quality of the soil.

According to Silva et al. (2006), the community of soil macrofauna is considered to be a parameter that is sensitive to the impact of production systems, which makes possible its use as a tool for determining management options in agricultural systems. This work therefore proposes to demonstrate whether it is possible to change the community of soil fauna, and increase its diversity, by the successive application of pig slurry. The work aimed to evaluate the influence of successive applications of slurry on a community of soil fauna under a system of direct seeding.

\section{MATERIAL AND METHODS}

The study was carried out in an experimental area located in the town of Taquaruçu do Sul, RS, latitude $27^{\circ} 23^{\prime} 45.75^{\prime}$ ' S, longitude $53^{\circ} 25^{\prime} 45.92^{\prime}$ ' $\mathrm{W}$, at an altitude of $475 \mathrm{~m}$. The area is of gently rolling terrain, and the climate is subtropical type Cfa according to the Köppen classification, with annual rainfall between 1,800 and $2,100 \mathrm{~mm}$ and average annual temperatures around $18^{\circ} \mathrm{C}$ (MALUF, 2000).

The soil at the site was characterised as a Oxisol (SOIL SURVEY STAFF, 1999), cultivated with annual crops such as soybeans, maize, oats and wheat, under a system of direct seeding. Analysis of the soil revealed the following physical and chemical characteristics, following a methodology of EMBRAPA (1997): $29 \%$ clay; $5.6 \mathrm{pH}$ $\mathrm{H}_{2} \mathrm{O} ; 2.2 \mathrm{mg} \mathrm{P} \mathrm{dm}{ }^{3}$ (Mehlich-1); $0.17 \mathrm{cmol}_{\mathrm{c}} \mathrm{Kdm}^{-3} ; 10.1 \mathrm{cmol}_{c}$ $\mathrm{Ca}^{2+} \mathrm{dm}^{3} ; 3.0 \mathrm{cmol}_{\mathrm{c}} \mathrm{Mg}^{2+} \mathrm{dm}^{-3}$ and $2.3 \%$ organic matter.

The experimental design was of randomised blocks in a $(4+1) \times 4$ factorial scheme, comprising five doses of fertiliser: 0 (no fertiliser), 20, 40 and $80 \mathrm{~m}^{3}$ of pig slurry ha-1 with one additional treatment of mineral fertiliser (MF), and four evaluations of the soil fauna, corresponding to the first, second, third and fourth application of pig slurry, with four replications. Assessments of the soil fauna took place after application of the pig slurry, and were carried out in the winter of 2009, summer of 2010 , winter of 2010 and summer of 2011.

Samples were collected from the residue of oats in the winter and maize in the summer. Traps were installed five days after application of the pig slurry, and remained in the field for five days. The MF was based on the soil analysis, interpreted using recommendations for maize, made available by the Laboratory Network for Soil Analysis of the South of Brazil (SOCIEDADE BRASILEIRA DE CIÊNCIA DO SOLO, 2004).

The survey of soil fauna was carried out on plots of $30 \mathrm{~m}^{2}$, in an experiment whose aim was to evaluate the fertilising potential of the pig slurry. During the experiment, the applications of pig slurry were made by hand with the help of watering cans to control the volume being applied and standardise distribution in the plots; the applications were made ten days before planting the crops of oats (Avena strigosa Scherb) and maize (Zea mays L.). Four applications of pig slurry were therefore made in the experimental area. 
The soil organisms were collected with the help of PROVID traps, as proposed by Antoniolli et al. (2006). The traps remained in the field for five days, and contained $0.25 \mathrm{~L}$ of $70 \%$ ethanol for conserving the organisms. The soil organisms taken from the traps were identified for order or class with the help of a 60 $\mathrm{x}$ binocular magnifier, using illustrated identification keys (BUZZI, 2008).

From the count and identification of the soil organisms, the relative frequency of occurrence (RF\%) of the class or order was calculated, together with the total organism density, organism population for the Orders Colembola and Acarina, and the following indices of biodiversity:

Margalef richness, obtained with formula (1):

$I=(n-1) / \ln N$

where $n$ is the number of groups (class and order) and $N$ is the total number of individuals found in the sample.

Simpson's dominance index, given by (2):

$S=\sum(n i / N)^{2}$

where $n i$ is the number of individuals in group " $\mathrm{i}$ " (class, order) and $N$ is the total number of individuals found in the sample.

Shannon diversity index, by means of formula

(ODUM, 1986):

$H=-\sum P i \log P i$, with $P i=n i / N$
The count data underwent transformation $(\mathrm{X}+$ $0.5)^{0.5}$, with the parameters obtained then being submitted to F-test. To test for significant effect, the mean values for the qualitative parameter (number of applications) were compared by Tukey's test, while those of the quantitative parameter (doses of pig slurry) were subjected to regression analysis at a 5\% level of significance using the SISVAR statistical software (FERREIRA, 2008). The mean values of each of the quantitative treatments were also compared to the mean values for the MF by Dunnett's test $(\mathrm{p}<0.05)$. A study of the relation between the distribution of individuals from each taxonomic group and the applied treatments was performed by means of a ranking created by canonical correlation analysis (CCA), using the CANOCO 4.0 software (TER BRAAK; SMILAUER, 1998).

\section{RESULTS AND DISCUSSION}

The organisms of soil fauna collected in the traps belonged to the following taxonomic groups: Acarina, Aranae, Collembola, Coleoptera, Diptera, Hemiptera, Orthoptera, larvae and Hymenoptera (Table 1). There was no significant interaction between the factors of variation in dose and number of applications; no simple effect was seen for the dose, nor for the difference in MF in relation to the dose of pig slurry, for the relative frequency of the groups of soil fauna (Table 1).

There was however a significant simple effect, but only for the number of applications (Table 1). Here, the Order Collembola displayed a greater relative frequency

Table 1 - ANOVA summary of the sources of variation: number of applications, dose, application $\mathrm{x}$ dose (A x D) of pig slurry, for relative frequency, in the groups Acarina (Aca), Araneae (Ara), Collembola (Col), Coleoptera (Clp), Diptera (Dip), Hemiptera (Hem), Hymenoptera (Hym), larvae (Home) and Orthoptera (Ort)

\begin{tabular}{|c|c|c|c|c|c|c|c|c|c|}
\hline & Aca & Ara & Col & Clp & Dip & Hym & Hem & Lar & Ort \\
\hline \multicolumn{10}{|c|}{ 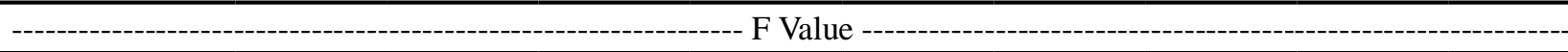 } \\
\hline Application (A) & $6.71 *$ & $3.16^{*}$ & 69.83* & $6.69 *$ & $15.25^{*}$ & $3.57 *$ & $56.13^{*}$ & $15.72 *$ & $47.75 *$ \\
\hline Dose (D) & 0.95 & 0.91 & 0.28 & 0.18 & 0.34 & 0.85 & 0.30 & 1.47 & 2.09 \\
\hline$A \times D$ & 0.65 & 1.62 & 0.67 & 0.79 & 0.40 & 0.92 & 0.51 & 1.36 & 2.10 \\
\hline Dunnett & $2.3^{\mathrm{ns}}$ & $1.8^{\mathrm{ns}}$ & $15.6^{\mathrm{ns}}$ & $2.3^{\mathrm{ns}}$ & $3.38^{\mathrm{ns}}$ & $1.5^{\mathrm{ns}}$ & $15.4^{\mathrm{ns}}$ & $5.32^{\mathrm{ns}}$ & $12.8^{\mathrm{ns}}$ \\
\hline $\mathrm{CV}(\%)$ & 45.3 & 36.56 & 28.4 & 45.5 & 40.7 & 49.4 & 39.7 & 71.2 & 34.84 \\
\hline \multicolumn{10}{|c|}{ 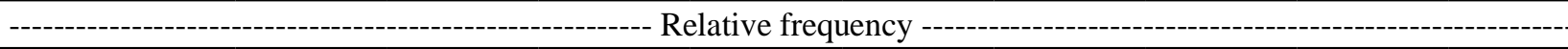 } \\
\hline $1^{\text {st }}$ Application & $0.2 \mathrm{c} * *$ & $0.0 \mathrm{~b}$ & $98.3 \mathrm{a}$ & $0.1 \mathrm{~b}$ & $0.9 \mathrm{~b}$ & $0.0 \mathrm{~b}$ & $0.4 \mathrm{~b}$ & $0.0 \mathrm{~b}$ & $0.0 \mathrm{~b}$ \\
\hline $2^{\text {nd }}$ Application & $7.8 \mathrm{~b}$ & $0.8 \mathrm{ab}$ & $61.5 b$ & $0.4 \mathrm{~b}$ & $2.0 \mathrm{~b}$ & $11.2 \mathrm{a}$ & $4.1 \mathrm{a}$ & $9.0 \mathrm{a}$ & $3.2 \mathrm{a}$ \\
\hline $3^{\text {rd }}$ Application & $12.2 \mathrm{ab}$ & $0.4 \mathrm{~b}$ & $77.8 \mathrm{ab}$ & $0.3 \mathrm{~b}$ & $8.4 \mathrm{a}$ & $0.0 \mathrm{~b}$ & $0.7 \mathrm{~b}$ & $0.1 \mathrm{~b}$ & $0.0 \mathrm{~b}$ \\
\hline $4^{\text {th }}$ Application & $16.2 \mathrm{a}$ & $1.8 \mathrm{a}$ & $74.0 \mathrm{ab}$ & $2.6 \mathrm{a}$ & $1.4 \mathrm{~b}$ & $0.6 \mathrm{a}$ & $3.1 \mathrm{~b}$ & $0.2 \mathrm{~b}$ & $0.0 \mathrm{~b}$ \\
\hline
\end{tabular}


in absolute values than the other orders, only the second application significantly reduced the relative frequency (Table 1). Antoniolli et al. (2006) found that the Order Collembola was the most abundant in locations that received $80 \mathrm{~m}^{3}$ of pig slurry $\mathrm{ha}^{-1}$. Bandyopadhyaya et al. (2002) found that the application of slurry caused an increase in the population of individuals of the Order Collembola. The high relative frequency of springtails is considered to be natural for this group of soil fauna (BELLINGER et al., 2015), and may well be an indirect effect of products added to the soil on the multiplication of fungi considered the main nutritional source of springtails (ANTONIOLLI et al., 2013; CASSAGNE; GERS; GAUQUELIN, 2003).

The application of pig slurry caused an increase in the relative frequency of the Orders Acarina and Coleoptera (Table 1). Tessaro et al. (2013) also demonstrated an increase in individuals of the Order Coleoptera, but reported a certain sensitivity in this group to the application of high volumes of pig slurry, with a reduction at doses greater than $100 \mathrm{~m}^{3}$ $\mathrm{ha}^{-1}$. These organisms are important to the soil as they may act as saprophages, fragmenting plant residue, or as predators, feeding on other organisms (KRANTZ; WALTER, 2009; MOÇO et al., 2005).

The Orders Aranae and Hymenoptera displayed greater relative frequency with the second and fourth applications, Diptera with the third, and Hemiptera with the second application (Table 1). Although for these Orders there was a significant effect from the applications, it was not possible to correlate this result with successive applications of the slurry, which may be an effect of changes to the environment while carrying out the study. According to Fernandes et al. (2011), many groups of soil fauna are influenced by environmental conditions, especially relating to variations in temperature and humidity.
There was no interaction between dose and the four applications of pig slurry for the population of the Acarina and Collembola groups, neither for density, richness, Simpson's dominance index or the Shannon diversity index. Evaluating the isolated effect of the treatments, it was found that the dose had no significant effect on these parameters, nor did they differ from the MF by Dunnett's test (Table 2). Although some authors have demonstrated a positive result of the use of pig slurry on soil organisms (ANTONIOLLI et al., 2006; TESSARO et al., 2011), the effects caused by this practice depend on the composition of the slurry, which may be beneficial or harmful (ALVES et al., 2008), and the presence of ground cover, which contributes to an increase in the available energy and promotes the creation of favourable habitats for colonisation by invertebrate organisms (SILVA et al., 2007). In this case, the presence of straw on the surface, caused by the system of direct seeding, may have minimised the effect of the doses of slurry.

Analysing the isolated effect of the period of slurry application, it can be seen that the density of individuals was significantly higher with the first application, decreasing with subsequent applications (Figure 1A). Alves et al. (2008), evaluating soil fauna in a soil under the application of pig slurry, found values that demonstrate the sensitivity of the density of individuals to this type of fertilisation. Toxicity tests showed the lethality of the heavy metals $\mathrm{Cu}$ and $\mathrm{Zn}$, present in the pig slurry, on organisms of the Order Collembola, one specific group of soil fauna (SEGAT, 2012). This sensitivity of the organisms strengthens the possibility of their use as a parameter for determining management options in farming systems (BARETTA et al., 2007; SILVA et al., 2006). The result indicates that successive applications of pig slurry can result in a reduction in density of the soil fauna.

Table 2 - ANOVA summary of the sources of variation: number of applications, dose, applications x dose (A x D) of pig slurry, for the number of organisms of the Orders Acarina (Aca) and Collembola (Col), the total organism density (Den), the Margalef richness index (Ric), Simpson's dominance index (Dom) and Shannon diversity index (Div)

\begin{tabular}{|c|c|c|c|c|c|c|}
\hline Dose & Aca & Col & Den & Ric & Dom & Div \\
\hline \multicolumn{7}{|c|}{ - } \\
\hline Application (A) & $17.83^{*}$ & $135.53 *$ & $121.71 *$ & $27.42 *$ & $80.54^{*}$ & $119.91 *$ \\
\hline Dose (D) & 0.718 & 0.705 & 0.930 & 0.707 & 0.357 & 0.421 \\
\hline$A \times D$ & 0.569 & 1.337 & 1.248 & 0.536 & 1.681 & 1.301 \\
\hline Dunnett & $0.50^{\text {ns }}$ & $0.56^{\text {ns }}$ & $0.53^{\text {ns }}$ & $0.60^{\text {ns }}$ & $0.85^{\mathrm{ns}}$ & $0.87^{\mathrm{ns}}$ \\
\hline $\mathrm{CV}(\%)$ & 47.7 & 27.8 & 24.5 & 10.6 & 4.9 & 5.31 \\
\hline
\end{tabular}

ns: not significant by Dunnett's test at $5 \%$ probability, between the additional treatment and each dose; * p $\leq 0.05$ by F-test 
Figure 1 - Total numerical density of organisms (A), number of springtails (B), number of mites (C), Margalef richness index (D), Simpson's dominance index (E) and Shannon diversity index ( F), obtained from evaluation of the four applications of pig slurry under a system of direct seeding
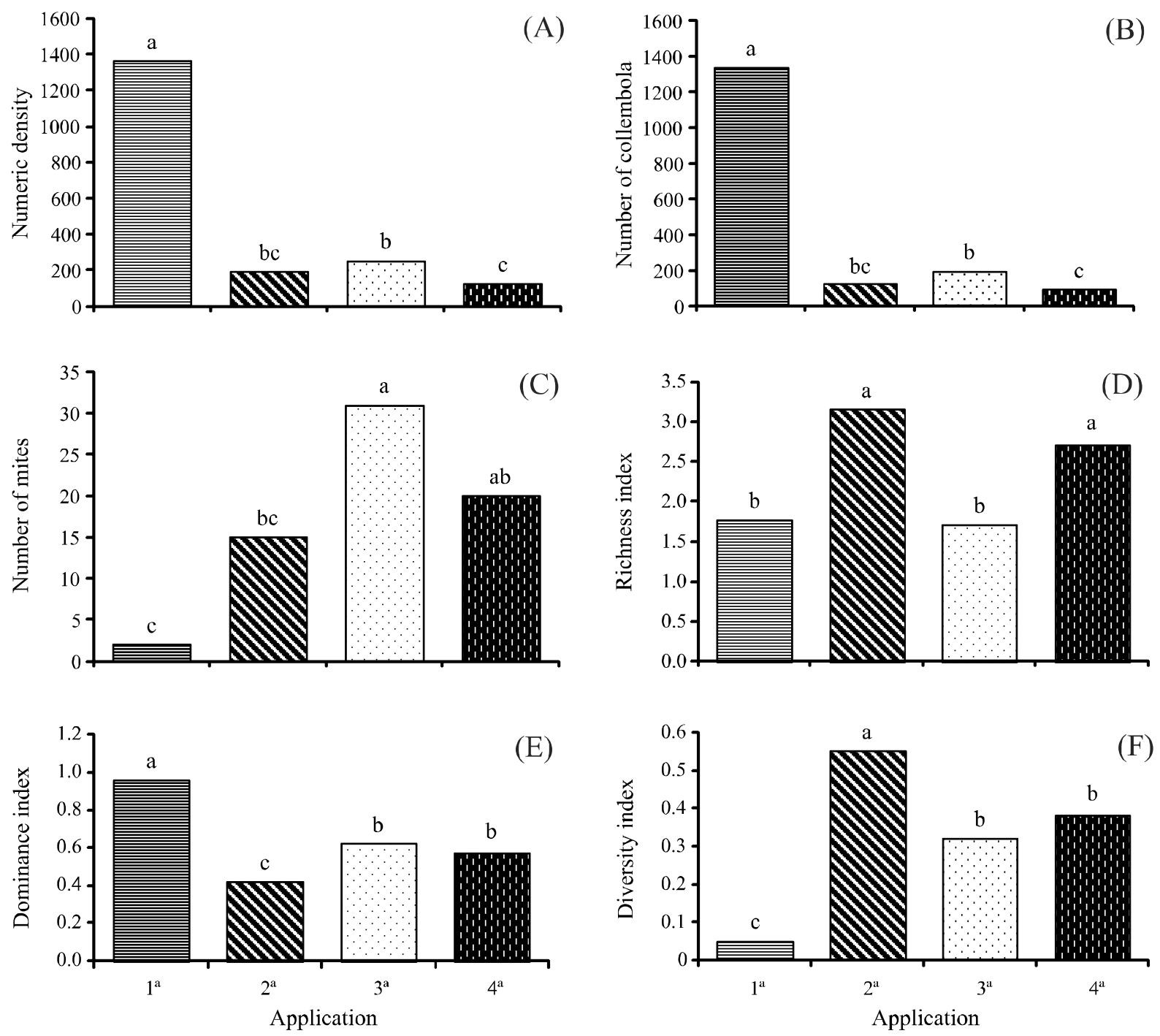

*Mean values followed by the same letter, within each analysed parameter, do not differ by Tukey's test at $5 \%$ probability $(\mathrm{p} \leq 0.05)$

The population of the Collembola group was greater after the first application, reducing with later applications (Figure 1B). Research has shown the negative action of $\mathrm{Cu}$ and $\mathrm{Zn}$ on the population of springtails (ANTONIOLLI et al., 2013), which is related to the toxic effects of the metals on the reproduction of these organisms (SANTORUFO et al., 2012). Ireson et al. (2002) showed that an increase in the number of soil mites resulted in a reduction in the population of springtails. Although $\mathrm{Cu}$ and $\mathrm{Zn}$ are present in pig slurry, it is possible that the reduction in the number of Collembola organisms is associated with the population of other soil arthropods, which are considered to be predators of the fauna, such as soil mites (KRANTZ; WALTER, 2009) (Figure 1C).

The population of organisms of the Order Acarina was higher in the evaluation carried out after the third application of pig slurry (winter, 2010), and was no different in the fourth application (SUMMER, 2011) (Figure 1C). Pig manure, handled in liquid form and stored in an anaerobic manure lagoon, is characterised by a low dry-matter content and a high percentage of ammoniacal nitrogen ( 40 to $70 \%$ of the total $\mathrm{N}$ ) (SANCHEZ; GONZÁLEZ, 2005). As per Ducatti (2002), mites occur in many ecosystems, and their population is 
increased by the addition of fertilizers which contain nitrogen, decreasing the number of their predators. The successive applications of pig slurry carried out in this work, together with the high nitrogen concentration found in this type of waste, made an increase in the population of soil mites possible.

Species richness was greater with the second and fourth applications of pig slurry (Figure 1D). The addition of organic residue in farming systems is a factor that can influence species richness, mainly due to supplying food to the organisms, and changes in temperature and ground cover (BARETTA et al., 2003).

The Simpson's dominance was greater in the evaluation made after the first application of pig slurry, and differed from the remaining applications (Figure 1E). These results are possibly due to the high number of springtails found after the first application (Table 1). According to Baretta et al. (2003) and Barreta et al. (2007), application of organic residue in agricultural systems, as in the case of pig slurry, can influence the communities of soil fauna. Application may favour the presence of some species, thereby turning them dominant. These results may explain the greater number of individuals of the Order Collembola after the first application of pig slurry, which favoured this dominance.

Shannon diversity was significantly lower with the first application of pig slurry, and higher with the second application (2010 summer) (Figure 1F). The greater number of springtails collected in the first evaluation (Table 1) may have led to a lower value for the
Shannon diversity, with the subsequent decrease of these individuals in the later collections possibly favouring an increase in the index. These results agree with those obtained by Alves et al. (2008), who attributed the lower values for diversity to the large number of individuals of any one order. However, those authors concluded that there was greater diversity in those treatments that received fertiliser containing pig slurry.

With the third application of pig slurry, the multivariate model that was used displayed a variation in the efficiency of the dose of slurry on the soil fauna community (Figure 2A). The total density and diversity of the soil organisms showed a greater relation to the MF treatment, and to a lesser extent, to the dose of $20 \mathrm{~m}^{3}$ of pig slurry ha ${ }^{-1}$, while the number of springtails was associated with the doses of 40 and $80 \mathrm{~m}^{3} \mathrm{~h}^{-1}$ (Figure 2A). This result confirms those of Antoniolli et al. (2006), who demonstrated a higher density of the Orders Collembola and Acarina in locations that received $80 \mathrm{~m}^{3}$ of pig slurry ha $\mathrm{h}^{-1}$. According to Tessaro et al. (2011), the Collembola group displays a higher density with doses of up to $200 \mathrm{~m}^{3} \mathrm{ha}^{-1}$. This result demonstrates the sensitivity of the multivariate analysis in analysing soil fauna, confirming the results of Baretta et al. (2006), who consider soil fauna to be a bio-indicator of the changes resulting from soil management, especially when using multivariate statistical tools.

With the fourth application (summer, 2011), multivariate analysis also shows a variation in the efficiency of the tested doses (Figure 2B). The total

Figure 2 - Graphical representation of the canonical correlation analysis (CCA) between the Shannon diversity index (Diversity), Simpson's dominance index (Dominance), total organism density (Total), and the population of springtails (Collembola), and the doses of $0,20,40$ and $80 \mathrm{~m}^{3}$ of pig slurry ha ${ }^{-1}$ and the additional treatment (mineral fertilizer - MF), after the third (winter, 2010) and fourth (summer, 2011) successive application

population of soil organisms showed a greater relation to the dose of $20 \mathrm{~m}^{3}$ of pig slurry ha-1 (Figure 2B), while the Simpson's dominance only displayed a tendency for association with the dose of $40 \mathrm{~m}^{3} \mathrm{ha}^{-1}$, and the springtails with the MF and the dose of $0 \mathrm{~m}^{3}$ of pig slurry ha- $\mathrm{ha}^{-1}$ The dose of $80 \mathrm{~m}^{3} \mathrm{ha}^{-1}$ did not display any association, as it was located between the diversity index and the number of springtails, and concentrated on the middle section of the axis.

It can be noted from this study that the application of pig slurry to the soil constitutes an alternative use for this waste, not causing changes in the soil fauna with increasing doses, and over time, decreasing the dominance of individuals inhabiting the soil, thereby favouring a greater diversity of soil fauna.

\section{CONCLUSION}

1. Successive applications of pig slurry increases the diversity of the soil fauna by reducing the population of organisms of the Order Collembola;

2. The Order Collembola was associated with the dose of $80 \mathrm{~m}^{3} \mathrm{ha}^{-1}$ after the third application of pig slurry, as demonstrated by canonical correlation analysis.

\section{REFERENCES}

AITA, C. et al. Decomposição de palha de aveia preta e dejetos de suínos em solo sob plantio direto. Revista Brasileira de Ciência do Solo, v. 30 p. 149-161, 2006.

ALVES, M. V. et al. Macrofauna do solo influenciada pelo uso de fertilizantes químicos e dejetos de suínos no Oeste do Estado de Santa Catarina. Revista Brasileira de Ciência do Solo, v. 32, p. 589-598, 2008.

ANTONIOLLI, Z. I. et al. Metais pesados, agrotóxicos e combustíveis: efeito na população de colêmbolos no solo. Ciência Rural, v. 43, n. 6, p. 992-998, 2013.

ANTONIOLLI, Z. I. et al. Método alternativo para estudar a fauna do solo. Ciência Florestal, v. 16, n. 4, p. 407-417, 2006.

AQUINO, A. M. de. et al. Invertebrate soil macrofauna under different ground cover plants in the no-till system in the Cerrado. European Journal of Soil Biology, v. 44, p. 91-97, 2008.

BANDYOPADHYAYA, I. et al. Effects of some physical factors and agricultural practices on Collembolla in a multiple cropping programme in west Bengal (India). European Journal Soil Biology, v. 38, n. 1, p. 111-117, 2002.

BARETTA, D. et al. Earthworm populations sampled using collection methods in Atlantic Forests with Araucaria angustifolia. Scientia Agricola, n. 64, n. 4, p. 384-392, 2007.
BARETTA, D. et al. Efeito do cultivo do solo sobre a diversidade da fauna edáfica no planalto sul Catarinense. Revista de Ciências Agroveterinárias, v. 5, n. 2, p. 108-117, 2006.

BARETTA, D. et al. Fauna edáfica avaliada por armadilhas de catação manual afetada pelo manejo do solo na região oeste catarinense. Revista de Ciências Agroveterinárias, v. 2, p. 97106, 2003.

BARTZ, M. L. et al. The influence of land use systems on soil and surface litter fauna in the western region of Santa Catarina. Revista Ciência Agronômica, v. 45, n. 5, p. 880-887, 2014.

Bellinger, P. F. et al. Checklist of the Collembola of the world. Disponível em: <http://www.collembola.org>. Acesso em: 12 abr. 2015.

BUZZI, Z. J. Entomologia didática. 4. ed. Curitiba: UFPR, 2008. $348 \mathrm{p}$.

CASSAGNE, N.; GERS, C.; GAUQUELIN, T. Relationships between Collembola, soil chemistry and humus types in forest stands (France). Biology and Fertility of Soils, v. 37, p. 355$361,2003$.

CREPALDI, R. A. et al. Formigas como bioindicadores da qualidade do solo em sistema integrado lavoura pecuária. Ciência Rural, v. 44, n. 5, p. 781-787, 2014.

DAL BOSCO, T. C. et al. Utilização de água residuária de suinocultura em propriedade agrícola - estudo de caso. Irriga, v. 13, n. 01, p. 139-144, 2008.

DUCATTI, F. Fauna edáfica em fragmentos florestais e em áreas de reflorestamento com espécies da mata atlântica. 2002. 84 f. Dissertação (Mestrado em Recursos Florestais) - Escola Superior de Agricultura “Luiz de Queiroz”, Piracicaba, 2002.

EMPRESA BRASILEIRA DE PESQUISA AGROPECUÁRIA. Centro Nacional de Pesquisa de Solos . Manual de métodos de análises de solo. 2. ed. Rio de Janeiro, 1997. 212 p.

FERNANDES, M. M. et al. Influência de diferentes coberturas florestais na fauna do solo na Flona Mário Xavier, no município de Seropédica, RJ. Floresta, v. 41, p. 533-540, 2011.

FERREIRA, D. F. SISVAR: um programa para análises e ensino de estatística. Revista Symposium, v. 6, p. 36-41, 2008.

GIROTTO, E. et al. Acúmulo e formas de cobre e zinco no solo após aplicações sucessivas de dejeto líquido de suínos. Revista Brasileira de Ciência do Solo, v. 34, n. 3, p. 955-965, 2010.

IRESON, J. E. et al. Further investigations into the efficacy of Neomolgus capillatus (Kramer) (Acarina: Bdellidae) as a predator of Sminthurus viridis (L.) (Collembola: Sminthuridae). Australian Journal of Entomology, v. 41, p. 88-93, 2002.

KRANTZ, G. W.; WALTER, D. E. A Manual of Acarology. 3. ed. Lubbock, Texas: Texas Tech University Press, 2009. 807 p.

MALUF, J. R. T. Nova classificação climática do Estado do Rio Grande do Sul. Revista Brasileira de Agrometeorologia, v. 8, p. 141-150, 2000. 
MOÇO, M. K. et al. Caracterização da fauna edáfica em diferentes coberturas vegetais na região norte fluminense. Revista Brasileira de Ciência do Solo, v. 29, p. 555-564, 2005.

ODUM, E. P. Ecologia. Rio de janeiro: Ed. Guanabara, 1986. $434 \mathrm{p}$.

SÁNCHEZ, M.; GONZÁLEZ, J. L. The fertilizer value of pig slurry. I. Values depending on the type of operation. Bioresource Technology, v. 96, p. 1117-1123, 2005.

SANTORUFO, L. et al. Soil invertebrates as bioindicators of urban soil quality. Environmental Pollution, v. 161, p. 57-63, 2012.

SEGAT, J. C. Avaliação ecotoxicológica do uso de dejetos suínos em solos de Santa Catarina. 2012. 130 f. Dissertação (Mestrado em Solos e Nutrição de Plantas) - Curso de PósGraduação em Solos e Nutrição de Plantas, Escola Superior de Agricultura "Luiz de Queroz”, Piracicaba, 2012.

SILVA, R. F. da. et al. Macrofauna invertebrada do solo sob diferentes sistemas de produção em Latossolo da Região do Cerrado. Pesquisa Agropecuária Brasileira, v. 41, p. 697-704, 2006.

SILVA, R. F. da. et al. Macrofauna invertebrada edáfica em cultivo de mandioca sob sistemas de cobertura do solo. Pesquisa Agropecuária Brasileira, v. 42, p. 865-871, 2007.

SOCIEDADE BRASILEIRA DE CIÊNICA DO SOLO. Núcleo Regional Sul. Manual de adubação e de calagem para os estados de Rio Grande do Sul e Santa Catarina. 10. ed. Porto Alegre: Comissão de Química e Fertilidade do Solo, 2004. 400 p.

SOIL SURVEY STAFF., 1999. Soil Taxonomy: a basic system of soil classification for making and interpreting soil surveys. 2nd Edition. Natural Resources Conservation Service: U.S. Department of Agriculture Handbook.

TER BRAAK, C. J. F.; SMILAUER, P. CANOCO reference manual and user's guide to Canoco for Windows: software for canonical community ordination (version 4). Ithaca, New York: Microcomputer Power, 1998. 351 p.

TESSARO, D. et al. Edaphic mesofauna (springtails and mites) in soil cultivates with baby corn and treates with swine wastewater combined with chemical fertilization. Journal of Food, Agriculture and Environment, v. 9, n. 3-4, p. 983987, 2011.

TESSARO, D. et al. Macrofauna of soil treated with swine wastewater combined with chemical fertilization. African Journal of Agricultural Research, v. 8, n. 1, p. 86-92, 2013. 